\title{
English Language Preservice Teachers' Stages of Concern for Web 2.0 Technology Integration
}

\author{
Halil Kayaduman, Inonu University, ORCID ID: 0000-0001-5316-1893 \\ Ömer Delialioğlu, Middle East Technical University, ORCID ID: 0000-0001-6515-3516
}

\begin{abstract}
This study explores the English Language preservice teachers (PST)' stages of concern (SoC) for Web 2.0 technology integration in the Learning Technology by Design (LBD) based course. It aims to identify and better understand PSTs' concerns. Understanding the concerns has advantages of describing and addressing the needs of PSTs prior to actual in-service experiences. SoC model, a component of the Concerns-Based Adoption Model, was used as the theoretical framework. An embedded mixed methods design was implemented, which included 24 English language PSTs. The PSTs attended a semester-long course in which they were involved in $L B D$ activities that included Web 2.0 technologies. While the quantitative data were collected through the SoC questionnaire, the qualitative data were gathered from the focus group and individual interviews. According to the findings, the PSTs improved their knowledge and skills regarding Web 2.0 technology integration and increased the Consequence stage's intensity significantly. Namely, the PSTs gained an understanding of how to design technology-integrated lesson activities that can promote learning. The findings further identified that the Unconcerned, Informational, and Personal stages' intensities remained predominant and unchanged over the semester. Recommendations for addressing the PSTs' concerns include: integrating LBD activities into the English language teaching curriculum and reinforcing the LBD activities with modeling, mentoring, or teaching practices to assure PSTs' commitments for technology integration.

Keywords: English language teaching, learning technology by design, preservice teachers, stages of concern, technology adoption, web 2.0

Inonu University Journal of the Faculty of Education

Vol 22, No 2, 2021

pp. 1083-1114

DOI:

10.17679/inuefd. 837412

Article type:

Research article

Received : 08.12.2020

Accepted : 23.06.2021
\end{abstract}

\footnotetext{
Suggested Citation

Kayaduman, H., \& Delialioglu, Ö. (2021). English language preservice teachers' stages of concern for web 2.0 technology integration. inonu University Journal of the Faculty of Education, 22(2), 1083-1114. DOI: 10.17679/inuefd.837412
}

This article was produced from the first author's doctoral dissertation approved by Middle East Technical University, Graduate School of Applied and Natural Sciences, in August 2017. 


\section{Ingilizce Öğretmen Adaylarının Web 2.0 Teknoloji Entegrasyonu için Kaygı Aşamaları}

Halil Kayaduman, Inönü Üniversitesi, ORCID ID: 0000-0001-5316-1893

Ömer Delialioğlu, Orta Doğu Teknik Üniversitesi, ORCID ID: 0000-0001-6515-3516

Öz

Bu çalışma, ingilizce öğretmen adaylarının, Teknolojiyi Tasarlayarak Öğrenme (TTÖ) yaklaşımı tabanında hazırlanmış bir derste, Web 2.0 teknoloji entegrasyonuna yönelik kaygı aşamalarını araştırmaktadır. Çalışma öğretmen adaylarının kaygılarını belirlemeyi ve daha iyi anlamayı amaçlamaktadır. Öğretmen adaylarının bu konudaki kaygılarını araştırmak, asıl hizmet içi deneyimlerden önce ihtiyaçları tanımlama ve ele alma fırsatını sunmaktadır. Çalışmanın teorik çerçevesi olarak Kaygı tabanlı adaptasyon modelinin bir bileşini olan Kaygı aşamaları kullanılmıştır. 24 ingilizce öğretmen adayını içeren gömülü bir karma yöntem tasarımı uygulanmıştır. Öğretmen adayları, Web 2.0 teknolojileri içeren TTÖ aktivitelerinin uygulandığı derse bir dönem boyunca katılmışlardır. Çalışmadaki nicel veriler kaygı aşamaları ölçeği ile toplanırken, nitel veriler odak grup ve bireysel görüşmelerden alınmıştır. Bulgular, öğretmen adaylarının Web 2.0 teknolojilerine yönelik bilgi ve becerilerinin geliştiğini ve kaygı aşamalarından biri olan Sonuç aşamasının yoğunluğunun istatistiksel olarak arttığını göstermiştir. Diğer bir ifadeyle, öğretmen adayları ögrenmeyi artırabilmek amacıyla teknoloji ile desteklenmiş ders etkinliklerinin tasarımı konusunda bir anlayış kazanmışlardır. Bulgular ayrıca Kaygısız, Bilgilendirici ve Kişisel aşamaların yoğunluklarının dönem boyunca baskın ve değişmeden kaldığını da ortaya koymuştur. Bu doğrultuda, bu çalışma öğretmen adaylarının teknoloji entegrasyonuna yönelik kararlııklarını sağlamak için, TTÖ etkinliklerinin ingilizce öğretimi müfredatına entegre edilmesini ve bu etkinliklerin modelleme, mentorluk yada ögretim deneyimi uygulamaları ile zenginleştirilmesini önermektedir.

Anahtar Kelimeler: İngilizce dili öğretimi, kaygı aşamaları, öğretmen adayları, teknoloji adaptasyonu, teknolojiyi

Gönderim Tarihi :

08.12.2020

Kabul Tarihi :

23.06.2021

Önerilen Atıf

Kayaduman, H., \& Delialioglu, Ö. (2021). İngilizce öğretmen adaylarının web 2.0 teknoloji entegrasyonu için kaygı aşamaları. Inönü Üniversitesi Eğitim Fakültesi Dergisi, 22(2), 1083-1114. DOI: 10.17679/inuefd.837412 


\section{English Language Preservice Teachers' Stages of Concern for}

\section{Web 2.0 Technology Integration}

Web 2.0 technologies (blogs, wikis, social networking, etc.) are becoming widespread in education. These technologies provide a collaborative learning environment in which students can become active in their learning process, create their knowledge by working online with their peers, and develop higher-order thinking skills (Fırat \& Koksal, 2017; O'Reilly, 2005; Orehovacki, Bubas \& Konecki, 2009; Penrod, 2007). Moreover, in language learning and teaching context, students can promote foreign language skills (Ducate \& Lomicka, 2008; Kessler, 2009; Kontogeorgi, 2014), increase motivation for learning (Aşıksoy, 2018; Jauregi \& Banados, 2008; Sari, 2019), and confidence for communication (Antenos-Conforti, 2009). Considering these, it is important to understand the implementations and to facilitate the processes related to the integration of Web 2.0 technologies in language learning and teaching context.

Integrating technologies into instruction can be difficult if practitioners feel discomfort or have concerns regarding implementation. Technological tools may be innovative and provide several advantages, but practitioners' concerns may prevent successful implementation (Hall, 1976; McArthur, 2008; Wexler, 2003). Since concerns influence the sense of self-efficacy and eventually the performance (Bandura, 1997; Boz \& Boz, 2010; Ghaith \& Shaaban, 1999; Hall \& Hord, 2014; Kayaduman \& Demirel, 2019), investigating concerns becomes a crucial consideration for successful and sustainable technology integration practices.

\section{Literature Review}

Preservice teachers (PSTs) are considered to be an integral part of technology integration and their decisions and degree of preparedness influence future implementations (Groth, Dunlap \& Kidd, 2007; Gülbahar, 2008; Handal, Campbell \& Perkins, 2019; Sadaf, Newby 
\& Ertmer, 2016). Although many PSTs seem comfortable with using Web 2.0 technologies (Kumar \& Vigil, 2011), they are considered as new to integrating them into their prospective instruction (Goktas, Yildirim \&Yildirim, 2009; Waycott et al., 2010). Research studies indicate, therefore, that PSTs have concerns (Cullen \& Greene, 2011; Hur et al., 2015) and are not wellprepared to integrate Web 2.0 technologies into their prospective instructions (Goktas et al., 2009; Lei, 2009).

In the language learning and teaching context, research studies reported that the PSTs have positive beliefs about the use of web technologies and use them for their daily life (Aşıksoy, 2018; Sari, 2019). However, when they become in-service teachers, most of them become reluctant to utilize them in their teaching (Faizi, 2018). Considering that English language learning is beyond a classroom experience (Cephe \& Balcikanli, 2012) and the web technologies could offer many opportunities to facilitate the learning process to occur outside of the classroom (Aşıksoy, 2018; Kontogeorgi, 2014; Sari, 2019), investigating the English language PSTs' concerns that might cause reluctance to use Web 2.0 technologies in their prospective teaching become critical importance since their beliefs are mostly formed in teacher education programs (Borg, 2011).

Concerns of people have been the focus of many research studies, and it is defined as "the composite representations of feelings, preoccupations, thoughts, and considerations given to a particular issue or task" (Hall \& George, 1979, p.8). Many research studies stated concern as a critical factor that impacts the people's decisions and actions related to technology integration (Anderson \& Maninger, 2007; Boz \& Boz, 2010; Burke et al., 2018; Ghaith \& Shaaban, 1999; Hall \& Hord, 2014; Lochner, Conrad \& Graham, 2015; Teo, 2009). Wexler (2003) noted that educators' concerns influence successful technology integration. Hall (1976) stated that people's concerns directly influence their performances. Furthermore, Hall and Hord (2014) expressed that the design of teacher education programs should exist in parallel with the developing concerns of PSTs rather than in accordance with the professors' 
concerns. Preparing teacher education programs based on the concerns of PSTs can thus facilitate the PSTs' technology adoption process for future implementation.

Technology integration is a complex process involving many interrelated factors (Karaca, Can \& Yildirim, 2013). PSTs' attitudes towards technology (Teo, Lee \& Chai, 2008), self-efficacy beliefs (Ertmer \& Ottenbreit-Leftwich, 2010), and concerns such as lack of technology resources in their future schools, the applicability of technology to their major field, and their skill and knowledge (Cullen \& Greene, 2011; Hur et al., 2015) might be influential on their decisions and actions for technology integration. Hence, preparing PSTs for technology integration may require various types of instructional activities that can address these factors. Quadrini (2013) stated that providing opportunities for PSTs to participate in a learning environment in which they can design and implement different methods and strategies can increase the chances of successful technology integration. Hence, the Learning Technology by Design (LBD) approach was integrated into the present study so that PSTs can design and implement different instructional methods and strategies with the help of technologies. In LBD, learners study collaboratively to learn the content by exploring, designing, revising, and reflecting (Kolodner, 2002). PSTs in LBD approach can have opportunities to improve their technology integration skills, self-efficacy and change their attitudes toward implementing technology in their prospective teaching (Alayyar, 2011; Johnson, 2012; Koehler \& Mishra, 2005). Moreover, in terms of language learning and teaching, LBD can increase PSTs' technological pedagogical content knowledge (TPACK) and technology integration self-efficacy beliefs (Kayaduman \& Delialioglu, 2017; Kurt, Mishra \& Kocoglu, 2013); it can change PSTs' concerns in regard to collaboration with peers and provide perspective for PSTs about the effects of Web 2.0 technologies on learning (Kayaduman \& Delialioglu, 2016). Therefore, learning activities in the present study are based on the LBD approach to provide opportunities for PSTs to develop the necessary skills and comfort level for technology integration. Understanding the reasons for their concerns while they involve in 
the LBD approach helps to reveal any unseen issues that may hinder future technology integration decisions and implementations.

In the literature, there are research studies related to courses and training to enhance the technology integration skills of PSTs (Alayyar, 2011; Hall, 2018; Johnson, 2012; Kalota \& Hung, 2013; Koehler \& Mishra, 2005; Lee \& Lee, 2014). The studies are also available regarding the exploration of PSTs' attitudes, awareness, and perceptions toward Web 2.0 technologies (Aşıksoy, 2018; Faizi, 2018). However, the research studies exploring how PSTs' concerns are formed for technology integration in teacher education programs are relatively scarce. In this regard, there is an increasing need for theory-driven examination of the concerns of PSTs when learning Web 2.0 technology integration. Investigating the PSTs' concerns can reveal issues that might obstruct future technology integration decisions and implementations. Furthermore, insights from the present study can help to design and develop more appropriate programs for teacher education institutions.

\section{Theoretical Framework}

In the present study, Stages of Concern (SoC), a component of the Concerns-Based Adoption Model (CBAM) was used as a theoretical framework, and it is defined as the developmental patterns of individuals' feelings and perceptions toward innovation and described as the personal side of change (Hall \& Hord, 2014). Understanding the change process of PSTs becomes a crucial consideration to fulfill the successful technology adoption in educational settings. While the Diffusion of Innovation (Dol) theory (Rogers, 2003) also deals with change, CBAM provides the basis for the current study. The difference between Dol and CBAM is their focus: while Dol focuses on individuals who actively participate in the change process (Rogers, 2003), CBAM focuses on the implementation process in which concern profiles are assessed to support the change process (Hall \& Hord, 2014). Considering that, CBAM was used as the theoretical framework. 
Concern is understood in different stages in the SoC model because an individual experiences a particular type of concern quite intensely at a time, then as that concern subsides, another concern arises (Hall \&Hord, 2014). These stages are: Unconcerned, Informational, Personal, Management, Consequence, Collaboration, and Refocusing (George, Hall \&Stiegelbauer, 2006). Each type of concern is neither good nor bad, and it is important to consider the concerns of individuals while forming the programs to promote their involvement (Hall \&Hord, 2001). Therefore, SoC is a critical framework for addressing the needs and wishes of individuals (Chen \& Jang, 2014; Kayaduman \& Demirel, 2019; Yang \& Huang, 2008).

\section{Purpose of The Study}

The present study explored the English Language preservice teachers' stages of concerns for Web 2.0 technology integration in the Learning Technology by Design-based course. It aims to identify and better understand preservice teachers' concerns. Understanding the concerns has advantages of describing and addressing the needs of preservice teachers prior to actual in-service experiences. The following research questions guided the study:

1. How did the English language preservice teachers' stages of concerns for Web 2.0 technology integration evolve in the Learning Technology by Design-based course?

1.1. What were the opinions of preservice teachers about the implementation of the Learning Technology by Design activities in the course?

1.2. What were the preservice teachers' concerns for Web 2.0 technology integration after the Learning Technology by Design-based course?

\section{Method}

An embedded mixed methods design (Creswell \& Clark, 2007) was used in this study. The primary basis of the mixed methods research study is that qualitative and quantitative data provide a better understanding of research problems. Both forms of data were utilized in the current study to identify and better understand the preservice teachers' concerns during their technology integration into English language teaching. In an embedded mixed-method 
design, one data format provides a supporting role for another data format (Creswell \& Clark, 2007). Creswell and Clark (2007) stated that the secondary data source would not be meaningful if they were not embedded in the primary source of data. Considering that, the qualitative data was used as a secondary data source and embedded in quantitative data to provide a rich analysis of the topic since it does not merely inform the concerns and the reasons behind them.

\section{Participants}

The PSTs in this study are from the department of Foreign Language Education. Upon graduation, they can become English language teachers in primary, secondary, and higher education institutions. This study consisted of 24 sophomore-level English language PSTs (22 females and two males) registered in the Instructional Principles and Methods course. A purposeful sampling method (Babbie, 2001) was used to answer the research questions. Participants enrolled in this particular course were chosen for this study as it is the first course PSTs take to learn instructional methods, strategies, and planning. While they learn how to design effective instruction, they have the opportunity to concurrently discover how to integrate Web 2.0 technologies into their pedagogies. Tables 1 and 2 present the PSTs' experience with Web 2.0 technologies and their level of Web 2.0 technology usage at the beginning of the semester. 
Table 1

Preservice Teachers' Length of use of Web 2.0 technologies for Daily Use

\begin{tabular}{lll}
\hline Time & f & Percent \\
\hline Never & 0 & 0 \\
1 Year & 4 & 16.67 \\
2 Years & 3 & 12.50 \\
3 Years & 9 & 37.50 \\
4 Years & 9 & 0 \\
& 0 & 33.33 \\
5 Years or more & 8 & \\
\hline
\end{tabular}

Table 2

Preservice Teachers' Self-Reported Level of Web 2.0 Technology Use

\begin{tabular}{lll}
\hline Level of Use & $f$ & Percent \\
\hline Non-User & 0 & 0 \\
Novice & 3 & 12.50 \\
Intermediate & 19 & 79.17 \\
Old Hand User & 2 & 8.34 \\
Past User & 0 & 0 \\
\hline
\end{tabular}

\section{Procedure}

The present study was integrated into the Instructional Principles and Methods course, which is a fundamental course for sophomore-level PSTs to develop understandings about principles of effective learning and teaching, instructional methods, strategies, and design 
(YÖK, 2018). The course was not technology-oriented, and PSTs were expected to gain an understanding of effective instruction and design a lesson by using a variety of instructional methods and strategies. In this study, the course content and LBD activities were combined to provide opportunities for PSTs to learn both instructional design and technology integration concurrently. This course took place over 14 weeks at a developed university in Turkey. While the course professor first carried out lecturing and discussion session, the researcher then implemented design activities regarding the week's topic. That is, the PSTs first gained knowledge regarding the week's topic and then implemented it in the design activities by integrating Web 2.0 technologies. These design activities consisted of exploration, design, revision, and reflection phases as suggested by Kolodner (2002), and the implementations conducted in these phases were explained below. In addition to the most commonly used Web 2.0 technologies in English Language Teaching (ELT) literature, Web 2.0 technologies were chosen based on criteria evaluating their usefulness, effectiveness, efficiencies, and appropriateness to the week's topic. While Zimmertwinsatschool, Bubbl.us, Quizlet, Blogger, Socrative, and Facebook tools were utilized in the design activities, Wikibook and Google documents were used to support collaborative writing and peer feedback sessions. The weekly procedure was as follows:

- Lecturing and Discussion: The PSTs first study the reading documents before the class. The course professor lectures and discusses the topic in the class. The PSTs then attend design activities to implement the topic by integrating Web 2.0 technologies.

- LBD-the exploration phase: the PSTs examine and report the Web 2.0 technology by identifying its main features, pedagogical affordances, and limitations.

- LBD-the design phase: the PSTs first write goals and objectives for a lesson activity by choosing a topic from the ELT curriculum of the primary, secondary, or tertiary education. Then, they design a lesson activity by considering the week's topic to attain written goals and objectives. In the lesson activity, the PSTs are supposed to utilize 
Web 2.0 technology that they examine in the exploration phase to facilitate the implementation of the lesson activity.

- LBD-the revision phase: the researcher first provides feedback on the designed lesson activities by examining the harmony of written goals and objectives, instructional methods and strategies, and utilization of the Web 2.0 technology. Accordingly, the PSTs revise their lesson activities.

- LBD-the reflection phase: the PSTs reflect on what they learned in this LBD process. At the beginning of the semester, the course professor and researcher introduced the course, explained what Web 2.0 tools are and how they can be used in language teaching. As a pre-test, they administered the Stages of Concern Questionnaire (SoCQ) online in English. Then they implemented the following topics: learning and teaching concepts, learning and instructional theories, the effect of technologies on learning and teaching, the instructional design frameworks, technological pedagogical content knowledge, instructional goals and objectives, selecting and implementing instructional strategies, direct and indirect teaching methods, supporting instruction with technology, organization of instruction, thematic planning and its relation to technology integration, and formative and summative assessment. According to the topics, the PSTs attended six design activities during the semester. As a group course project, PSTs developed comprehensive technology-integrated lesson plans via Wikibook. Then, the groups provided peer feedback on each other's lesson plans using Google Documents. During the semester, three different focus group interviews were administered after the design activities to investigate the PSTs' opinions about LBD activities. After the semester ended, the PSTs took the post-test and joined the individual interviews. Figure 1 illustrates the procedure of the study. 


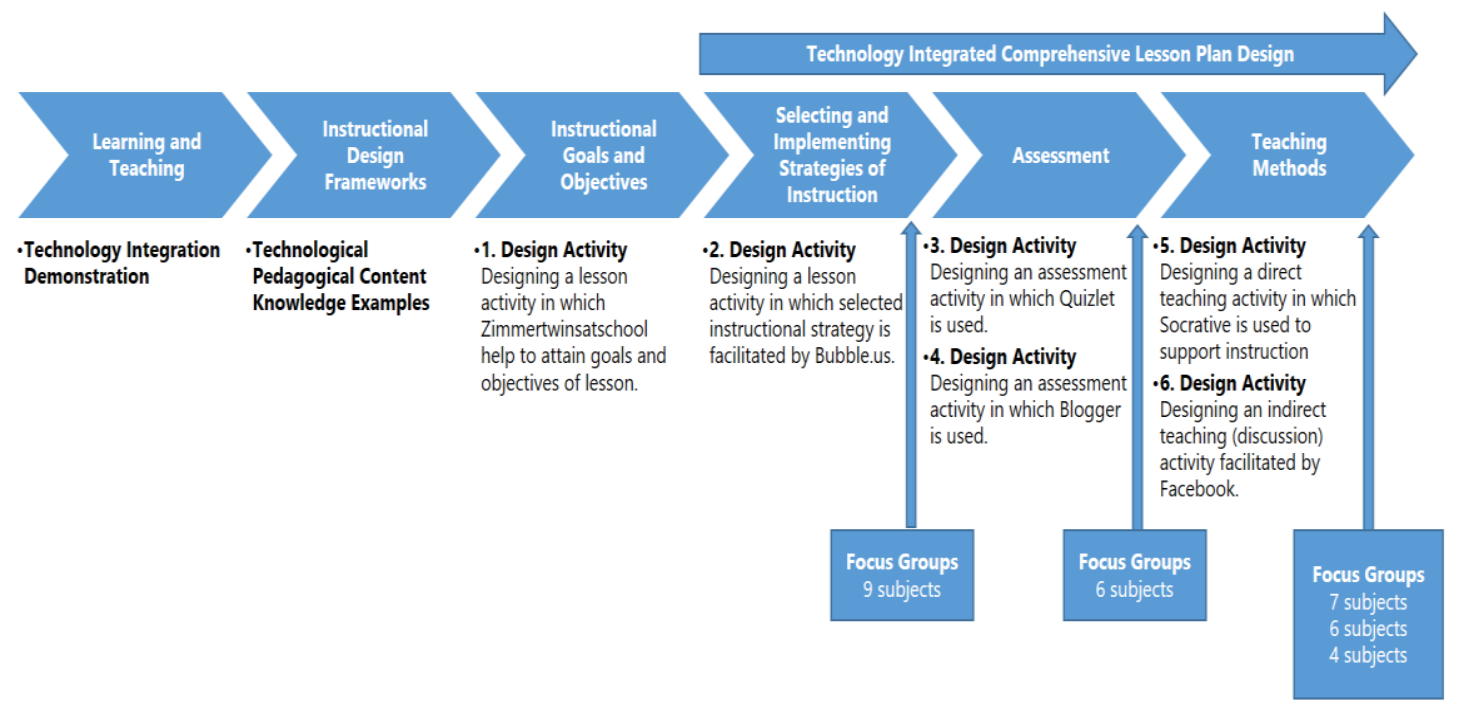

Figure 1. The Procedure of the Study

\section{Instruments}

Stages of Concern Questionnaire. A Stages of Concern Questionnaire (SoCQ) (George et al., 2006) was used to measure the SoC of PSTs about integrating Web 2.0 tools into ELT. The questionnaire has a 7-point Likert scale and 35 items. The questionnaire's coefficient values for internal reliability range from a minimum of 0.64 to a maximum of 0.83 . Considering the minimum criteria of being above 0.70 for internal reliability (Büyüköztürk, 2009), six of the seven stages of concerns were above 0.70 . Stage 0 ( 0.64 internal reliability) was only below 0.70 criteria, and it was not removed from the study considering its representation for lack of knowledge and interest (George et al., 2006). Besides, the values of the test-retest correlation range from 0.65 to 0.86 , with six of the seven correlations being above 0.70 . The word "innovation" was replaced with "Web 2.0 tools" in the instrument, which abides by the questionnaire instruction (George et al., 2006).

Interview Forms. The focus group and individual interviews were designed to investigate the PSTs' SoC in detail. In addition to convenience sampling, the criteria for choosing interview participants were to attend the design activities. The focus group interviews were designed to understand the opinions of PSTs about LBD activities and included questions such as the PSTs' opinions about the design activities, the difficulties that PSTs had 
while doing the activity, and how the activity affected the knowledge and skills in designing technology-supported instruction. Besides, the individual interviews aimed to reveal the present SoC of PSTs after the course and included questions such as the PSTs' interests and knowledge of Web 2.0 technologies, their considerations of integrating them into ELT, the effects of integrating Web 2.0 technologies on their profession, classroom management, and prospective students. Two experts holding doctoral degrees in the field of Educational Technology checked the appropriateness of questions and finalized the interviews.

\section{Data Analysis}

Quantitative data from the pre and post-tests were analyzed using a paired sample ttest (Pallant, 2007). As the assumptions (Field, 2009) were not violated, it was appropriate to conduct a paired sample t-test. As for the quantitative data, the researcher transcribed the interview data verbatim and then followed the descriptive and content analysis procedures (Yıldırım \& Şimşek, 2013). Since the theoretical framework of the study was explicit, the preliminary themes were defined based on SoC. Following, data was processed to reveal any unforeseen concepts and themes in the data, and findings were subsequently described and interpreted based on these stages. Each qualitative finding was embedded in the associated quantitative findings to gain a better understanding of the present study's results.

\section{Validity and Reliability}

Different strategies were employed to ensure validity and reliability. First, the triangulation strategy (Patton, 2001) was used to establish credibility. The researcher administered the SoCQ and conducted interviews. Having different sources of data provided opportunities to triangulate the data and analyze them from a broad perspective. Second, the reasoning behind employing an embedded mixed methods design, the study's participants, and procedures were described in detail for transferability. Third, the inter-coder reliability score using Miles and Huberman's (1994) formula was calculated for interviews. 


$$
\text { Reliability }=\frac{\text { Number of agreements }}{\text { Number of agreements }+ \text { Number of disagreements }}
$$

A Ph.D. student in the Faculty of Education also coded the data. A $90 \%$ agreement score for the focus group and a $96 \%$ agreement score for individual interviews were found, which were appropriate scores for inter-coder reliability (Miles \& Huberman, 1994). Fourth, a prolonged engagement strategy (Lincoln \& Guba, 1985) was utilized to establish the validity of the study. The researcher attended all sessions of the course, led the design activities, and collected quantitative and qualitative data. And lastly, peer debriefing sessions were conducted many times over the semester. The researcher discussed each step of the study with different Ph.D. students in the faculty of Education.

\section{Results}

The primary analysis of the present study was conducted using quantitative methods. SoC questionnaire was administered as pre and post-test at the beginning and end of the semester, and a paired sample t-test, presented in Table 3, was run to investigate how the PSTs' SoC for Web 2.0 technology integration changed in the LBD-based course.

\section{Table 3}

Descriptive Information and the Results of Paired Sample T-Test

\begin{tabular}{lllllllll}
\hline & \multicolumn{7}{l}{ Pre-Tests } & \multicolumn{7}{l}{ Post-Tests } & & & \\
& \multicolumn{1}{l}{} & $\mathrm{M}$ & $\mathrm{SD}$ & $\mathrm{M}$ & $\mathrm{SD}$ & $\mathrm{df}$ & $\mathrm{t}$ & $\mathrm{p}$ \\
\hline Unconcerned & 17.58 & 5.52 & 19.47 & 4.39 & 23 & -1.94 & 0.06 \\
Informational & 24.87 & 5.77 & 23.26 & 3.82 & 23 & 1.49 & 0.15 \\
Personal & 26.20 & 6.20 & 26.21 & 5.17 & 23 & 0.00 & 0.99 \\
Management & 18.66 & 6.47 & 19.39 & 6.62 & 23 & -0.48 & 0.63 \\
*Consequence & 22.75 & 6.58 & 25.52 & 4.87 & 23 & -2.34 & $0.02 *$ \\
Collaboration & 19.00 & 9.38 & 20.04 & 8.67 & 23 & -0.57 & 0.57 \\
Refocusing & 22.83 & 6.06 & 22.78 & 5.06 & 23 & 0.04 & 0.96 \\
\hline
\end{tabular}


Note: ${ }^{*} \mathrm{p}<0.05$

There was a significant increase in the Consequence stage from pre-test $(M=22.75$, $S D=6.58)$ to post-test scores $(M=25.52, S D=4.87), t(23)=-2.34, p=.02$. Eta squared value was also found to be 0.19 , indicating a large effect size (Pallant, 2007). That is, LBD activities increased the intensity of the Consequence stage, and the PSTs began to consider the possible effects of Web 2.0 technologies on potential students' attitudes and learning. However, the results also indicated that there were no significant differences in Unconcerned, Informational, Personal, Management, Collaboration, and Refocusing stages. That is, the PSTs' considerations on the interest of Web 2.0 technologies, requests for information about Web 2.0 integration, the effects of Web 2.0 integration on them, management concerns, and collaboration with colleagues remained unchanged compared to the beginning of the semester.

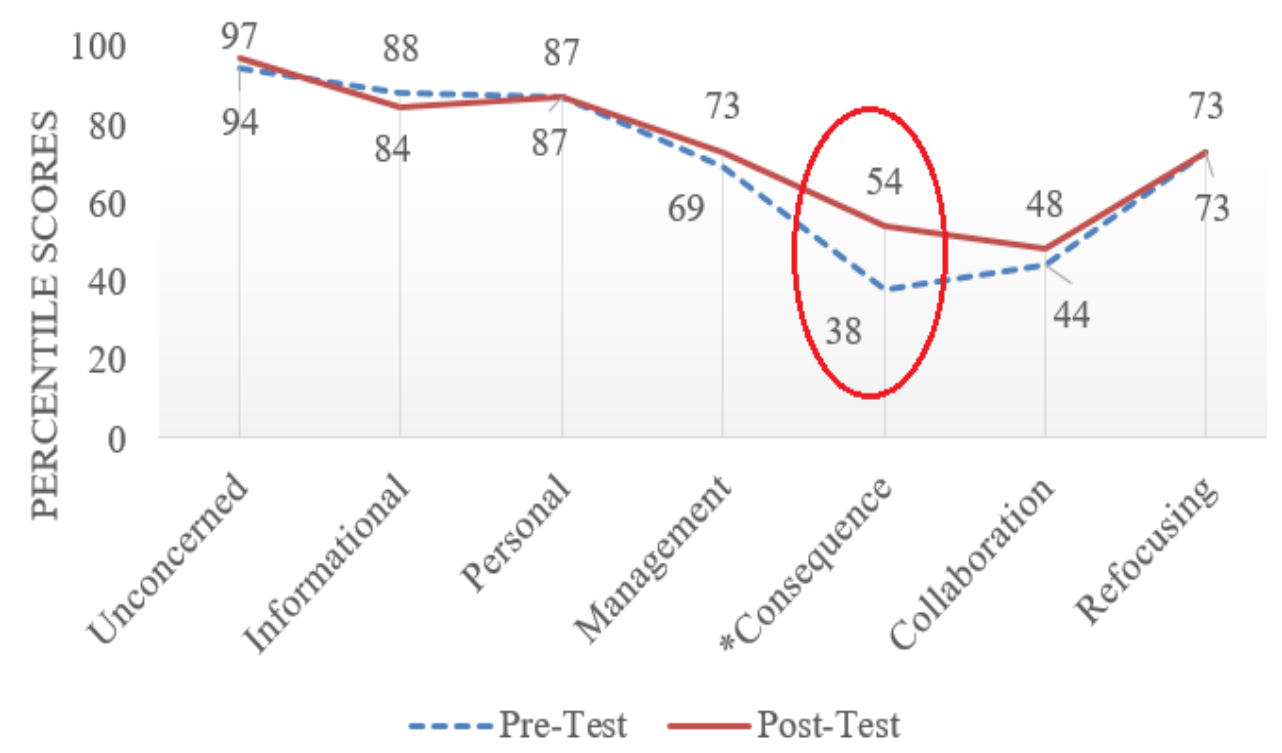

Figure 2. Group Percentile Scores

Group percentile scores, using the percentile conversion chart (George et al., 2006), were also calculated to identify the intensity and diversity of concerns within the group. The higher scores indicate that the PSTs experiences a concern more intensely than other stages. Figure 2 indicates that the predominant stages are around self-concerns and did not change 
after the LBD-based course. The figure also shows that the intensity of the Consequence stage increased dramatically, but it is still lower than self-concerns.

The secondary analysis of the present study was conducted using qualitative methods. The focus group and individual interviews were conducted to investigate the PSTs' opinions about LBD activities and the concerns for Web 2.0 technology integration after the course. As a result of qualitative analysis, the main themes and sub-themes and their frequencies are presented in Table 4 and Table 5. Each finding was associated with the related SoC to identify preservice teachers' concerns.

Table 4

The Preservice Teachers' Opinions about Learning Technology by Design Activities

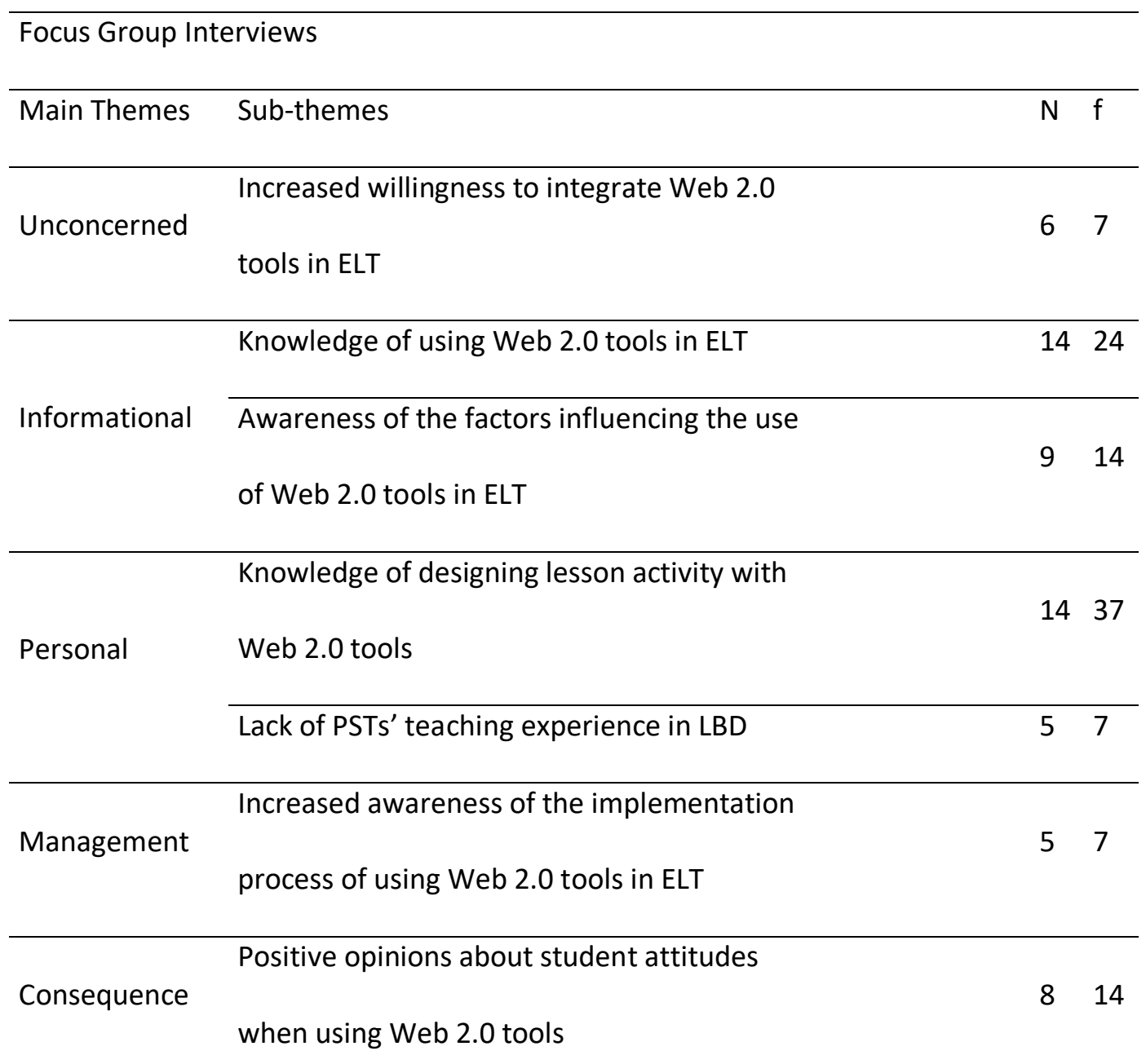


Positive opinions about the learning

outcomes of students when using Web 2.0

1228

tools

\begin{tabular}{|c|c|c|c|}
\hline \multirow{3}{*}{ Collaboration } & \multirow{3}{*}{ Thoughts about peer feedback } & \multirow[t]{2}{*}{ Benefits } & \multirow[t]{2}{*}{1218} \\
\hline & & & \\
\hline & & Drawbacks & 6 \\
\hline \multirow{3}{*}{ Refocusing } & Knowledge for enhancing Web 2.0 tools & & 2 \\
\hline & Intentions for the future usage of Web 2.0 & & \multirow[b]{2}{*}{9} \\
\hline & tools & & \\
\hline
\end{tabular}

Note: $\mathrm{f}=$ Code frequency, $\mathrm{N}=$ Number of Participant

Table 5

The Preservice Teachers' Concerns for Web 2.0 Technology Integration

Individual Interviews

\begin{tabular}{|c|c|c|c|c|}
\hline Main Themes & Sub-themes & & $\mathrm{N}$ & $f$ \\
\hline \multirow{3}{*}{ Unconcerned } & $\begin{array}{l}\text { Positive willingness to integrate Web } 2.0 \\
\text { tools in ELT }\end{array}$ & & 5 & 5 \\
\hline & $\begin{array}{l}\text { External Factors inhibiting PSTs' interest in } \\
\text { Web } 2.0 \text { tools }\end{array}$ & & 6 & 9 \\
\hline & $\begin{array}{l}\text { Internal Factors inhibiting PSTs' interest in } \\
\text { Web } 2.0 \text { tools }\end{array}$ & & 5 & 8 \\
\hline \multirow{4}{*}{ Informational } & Knowledge of using Web 2.0 tools in ELT & & 12 & 16 \\
\hline & & $\begin{array}{l}\text { Student } \\
\text { Competency }\end{array}$ & 4 & 4 \\
\hline & PSTs' use of Web 2.0 tools in ELT & Technical Facilities & 9 & 11 \\
\hline & & $\begin{array}{l}\text { Teacher } \\
\text { Competency }\end{array}$ & 8 & 8 \\
\hline
\end{tabular}


Willingness to learn more information

Positive

about Web 2.0 tools

Negative

11

The positive influence of using Web 2.0

tools on the teaching profession

The influences of using Web 2.0 tools on

Personal the role of the teacher in the classroom

\begin{tabular}{lcc}
\hline Lack of teaching experience & 8 & 18
\end{tabular}

\begin{tabular}{llll}
\hline Influence of using Web 2.0 tools in terms & Positive & 10 & 13
\end{tabular}

of teachers' allocated time and energy $\quad$ Negative $2 \quad 3$

Perceived difficulties in classroom

Management

management when using Web 2.0 tools

The positive influences of using Web 2.0

tools on the attitudes of students

Consequence

The positive influences of using Web 2.0 tools on the learning

outcomes of students

\begin{tabular}{|c|c|c|c|c|}
\hline \multirow{4}{*}{ Collaboration } & Willingness to collaborate with FLE & Positive & 8 & 11 \\
\hline & teachers & Negative & 3 & 3 \\
\hline & Willingness to collaborate with Other & Positive & 2 & 3 \\
\hline & teachers & Negative & 10 & 12 \\
\hline \multirow{3}{*}{ Refocusing } & Knowledge of enhancing Web 2.0 tools & & 10 & 11 \\
\hline & Intentions for the future usage of Web 2.0 & Positive & 11 & 21 \\
\hline & tools & Negative & 2 & 4 \\
\hline
\end{tabular}

$\mathrm{f}=$ Code frequency, $\mathrm{N}=$ Number of Participant

\section{Unconcerned}

There was no significant difference between pre- and post-test scores and it was the most intense stage over the semester. While some of the PSTs expressed in the focus group 
interviews that engaging in LBD activities increased their willingness to integrate Web 2.0 technologies in ELT, the intensity of the stage did not change significantly. Furthermore, in the individual interviews, PSTs noted external and internal factors that inhibited their interest in Web 2.0 technologies. Some of the external factors stated by PSTs include how they prioritized their major field and spent most of their time with the exams and assignments. One articulated:

We have to do more in our department and accordingly I have more responsibilities and homework for my department. I am interested [Web 2.0] but not much. So inevitably, I prioritize my grades and try to increase them...

Internal factors expressed by the PSTs include how they were not interested in using technologies; therefore, they are unconcerned with Web 2.0 technologies.

\section{Informational}

There was no significant difference between pre- and post-test scores. Figure 2 indicates that the intensity of the Informational stage is the second-highest concern and remains almost the same after the LBD activities. In the focus group interviews, PSTs stated that engaging in LBD activities helped them increase their knowledge of Web 2.0 technologies and learn on what conditions they could be used in ELT. One said:

Exploring the limitations and writing Web 2.0 tools' pros and cons contribute to our knowledge about where we can use these tools and where we cannot use them. In the individual interviews, all PSTs expressed that they were knowledgeable about Web 2.0 technologies. While some PSTs pointed out that Web 2.0 technologies could be used to develop the necessary skills of the English language, others said that they could be used in daily life and education. Besides, many PSTs emphasized the importance of technical facilities (e.g., computer and internet connection) and student and teacher digital competency as required factors influencing their use of Web 2.0 technologies. One stated: 
Firstly, I know that computer literacy is needed. We need to know what purposes we will use the tools. We need to know how to use computers. We need to know the features of that Web 2.0 tool so that we can use it depending on the features... Although the PSTs indicated that they are knowledgeable about Web 2.0 technologies and aware of the factors influencing their use, most PSTs stated that they must know more about Web 2.0 technologies to appeal to the digital era students' various needs and wishes.

\section{Personal}

There was no significant difference between pre- and post-test scores. Personal is the second most intense concern, along with the Informational stage. In the focus group interviews, many PSTs noted that engaging LBD activities increased their knowledge of designing lesson activities supported by Web 2.0 technologies. Furthermore, PSTs stated that they gained technology-integrated lesson activity ideas, learned how to associate the ELT topics to Web 2.0 technologies, and how to arrange their teaching to integrate Web 2.0 technologies. One noted:

...We learned about how we should use technologies, how we can associate the tools with the topics, how we can make them more relevant to our classes, and how we can benefit from these tools.

As well, many PSTs stated in the individual interviews that Web 2.0 technologies could reduce the time and efforts of teachers and positively influence their teaching profession. Many PSTs also expressed that their role in the classroom changed to that of a facilitator, and students became more active in their learning process. On the other hand, many PSTs underlined the importance of teaching experience. The PSTs emphasized that they designed their activities based on prediction due to lack of teaching experience, and did not practice these activities in a real classroom environment in the context of LBD. Therefore, they were not certain of the effects of Web 2.0 technologies. One expressed: 
We guess what kind of deficiencies we can have. When we implement it in the classroom, maybe there will be a deficiency of the tool that will never come to our mind. We think as if everything will happen perfectly.

\section{Management}

There was no significant difference between pre- and post-test scores and it remained almost the same intensity after LBD. In the focus group interviews, some PSTs pointed out that LBD activities increased their awareness about the implementation process of using Web 2.0 technologies in ELT. In this direction, many PSTs in the individual interviews stated that they could have difficulty managing a classroom when they integrated Web 2.0 technologies, as the Internet is very distracting and may hinder a student's ability to focus. One noted:

I think I will have difficulty with it because we are in the technology era. Even little children know how to use computers and the internet before learning writing and reading. Hence, students become distracted and I think I cannot control and manage the classroom.

\section{Consequence}

There was a significant mean difference between pre- and post-test scores with a large effect size. In the focus group interviews, many PSTs expressed that they learned different Web 2.0 technologies that can attract the attention of students, and considered how the activities designed with these technologies could have an impact on students. Therefore, they said that these tools can enhance the learning of the students by immersing them in the learning process. One said:

A language consists of a lot of skills such as vocabulary, speaking, listening, etc. I think teaching these skills with traditional methods is not easy. Hence, we can attract the attention of students, facilitate their learning by using different Web 2.0 tools considering the many options, especially for young learners. 


\section{Collaboration}

There was no significant difference between pre- and post-test scores and it was the lowest intense concern after the LBD activities. In the context of LBD, PSTs gave peer feedback on each other's lesson plans in addition to designing these plans collaboratively. In this process, many PSTs found peer feedback sessions beneficial: these sessions helped draw attention to missing points in their lesson plans and exposed PSTs to the many different design activities that can be used in ELT. Additionally, some of the PSTs expressed that they were not certain of the feedbacks since the peers were not experts and some of them were not objective during the session. As a result, while most of the PSTs stated in the individual interviews that they could collaborate with English language teachers since they teach the same content knowledge, they did not want to collaborate with teachers from other fields.

\section{Refocusing}

There was no significant difference between pre- and post-test scores. The interview data revealed that many PSTs asked to enhance the Web 2.0 technologies by considering the limitations that they confronted in the context of LBD activities. In terms of future usage, many PSTs expressed that they could integrate some of Web 2.0 technologies into their prospective classes if the necessary conditions were met.

\section{Discussion}

The present study explored the English Language PSTs' SoC for Web 2.0 technology integration in the LBD-based course. We designed a course in which LBD activities aligned with the course goals and objectives, and collected the data related to the PSTs' needs and progress. The findings indicated that the LBD-based course contributed to the PSTs' technology integration understandings: the PSTs increased their awareness and knowledge about integrating Web 2.0 technologies in ELT, the factors influencing the integration of Web 2.0 technologies, the possible effects of Web 2.0 technologies on themselves, and knowledge of enhancing Web 2.0 technologies. These findings are aligned with the extant literature which 
states that engaging in LBD activities can improve PSTs' technology integration understanding, knowledge, and skills (Alayyar, 2011; Fessakis, Tatsis \& Dimitracopoulou, 2008; Johnson, 2012; Koehler \& Mishra, 2005).

The findings provided further evidence about the PSTs' concerns. The PSTs' most intense concern over the semester was the Unconcerned stage. George et al. (2006) stated that individuals experiencing this stage intensely might have other considerations or activities. The findings revealed that some PSTs prioritized their major field, while others were uninterested in Web 2.0 technologies. Since the intense stage depends on the individuals' engagement (Toms, 1997), the PSTs' involvement with Web 2.0 technologies in ELT might be limited throughout the curriculum. Therefore, the PSTs might have indicated a high level of Unconcern due to considering technology integration independent from their major field.

Following to Unconcerned stage, self-concerns (Informational and Personal) were the most intense stages over the semester. While individuals have general knowledge and demand to learn more about innovation at the Informational stage, they consider their abilities and possible effects of using innovation on themselves at the Personal stage (George et al., 2006). The findings illustrated that the PSTs considered technology resources, students' and teacher's digital competencies as critical factors influencing their technology integration decisions. Besides, the PSTs stated that they had a lack of real teaching experience because they designed their technology-supported lesson activities based on prediction. Hall and Hord (2014) expressed that self-concerns might be due to self-efficacy issues. Since the PSTs could not perform their lesson activities in real settings and see their effects on them, they might have self-doubts about themselves and need of learning more about the details of integrating Web 2.0 technologies. Thus, they might indicate a high level of self-concerns. Also, many PSTs believed that when they integrated Web 2.0 technologies, they might have difficulty managing a classroom. At this point, Rogers (2003) noted that individuals should first implement innovation and see the consequences to adopt innovation in their classrooms. Therefore, the 
PSTs' lack of teaching experience may have also caused the intensity of the Management stage to remain the same throughout the semester.

The only significant difference in SoC was at the Consequence stage. Individuals at this stage consider how innovation affects learning outcomes (George et al., 2006). According to the findings, the PSTs believed that their technology-integrated lesson activities can attract students' attention, help them become active in their learning process, and thus result in satisfactory learning outcomes. At this point, Fessakis et al. (2008) stated that LBD activities can help teachers to provide appropriate learning experiences for their students. Kayaduman and Delialioglu (2016) also expressed that involvement in LBD activities can increase the PSTs' Consequence stage intensity. Therefore, the significant increase in the Consequence stage might be due to LBD activities which contributed to PSTs' understanding of designing effective technology-supported learning activities.

Although one of the impact concerns (Consequence, Collaboration, and Refocusing) increased significantly, the intensities of self (Informational and Personal) and awareness (Unconcerned) concerns remained predominant after the intervention. Previous studies (Chen \& Jang, 2014; George et al., 2006; Hall \& Hord, 2014; Hao \& Lee, 2017) showed that individuals tend to have a lower impact and higher self-concerns at the early phase of adoption. Considering the participants who are sophomore-level PSTs and just learned designing technology-supported instruction, they could consider more about their roles and competencies in this process, demand information to increase their knowledge and skills, and thus maintain these concerns.

\section{Conclusion and Implications}

The study has important implications for a better understanding of the components involved in technology integration. First, the present study developed an LBD-based course that could shape subsequent preservice and in-service teacher education programs. Integrating the LBD activities in preservice and in-service teacher education programs could be 
an effective way for technology integration. The LBD activities should be aligned with course goals and objectives and the Web 2.0 technologies chosen for the activities should be useful, effective, efficient, and appropriate to the week's subject. While LBD activities that were implemented in the present study influence the PSTs' technology adoption process by helping them acquire new knowledge and skills, this study further identified that the PSTs could gain an understanding of designing technology-supported learning activities that can improve students' learning.

Second, the PSTs in the study see technology integration as independent from their major field due to a high level of Unconcerned stage. Yang and Huang (2008) stated that considerable exposure to innovation decreases the intensity of the Unconcerned stage. Therefore, integrating LBD activities into the ELT curriculum, not just in the scope of a few courses, could further promote the PSTs' understanding of technology integration and reduce the intensity of the Unconcerned stage.

Third, the PSTs in the study were not certain the effects of Web 2.0 technology integration on themselves due to a lack of teaching experience, and thus had a persistent level of self-concerns. As the development of concerns depends on successful experiences (Alrawajfih, Fook \& Idros, 2010), providing opportunities for PSTs to see the consequences of technology integration implementations could be important. First-hand teaching experience practices might be useful at this point. However, it may not always be possible due to the number of PSTs and limited opportunities in schools. In this regard, modeling and mentoring could overcome these obstacles. Kim et al. (2008) revealed that faculty modeling on technology use is associated with PSTs' intentions to use technology. Similarly, OttenbreitLeftwich et al. (2018) found that preparing video mentoring sessions with in-service teachers can alleviate PSTs' concerns about technology integration. Therefore, the current study suggests reinforcing LBD activities with modeling, mentoring, or teaching experience practices 
to change the intensity of concerns from self to impact concerns and to assure PSTs' commitments for effective technology integration.

Lastly, the present study identified crucial aspects of PSTs' concerns. Informing faculty members, policymakers, and educational planners about the concerns and addressing them to establish interventions and strategies can lead to and promote the PSTs' usage of technological tools; in turn, this may yield more widespread effective technology integration in education at large.

\section{Future Research and Limitations}

Although the present study provided rich data and answered the guiding research questions, further studies are needed to gain a greater understanding of successful and sustainable technology adoption. The present study is limited by the participants who attended the Instructional Principles and Methods course. Additionally, the total number of 24 surveys formed a small sample size. Hence, the findings should cautiously be interpreted and future research should establish a larger sample size from different participants' backgrounds to investigate the concern development in greater depth. As well, future research would benefit from including different variables that might influence the PSTs' concerns, such as motivation and personal traits, and also by providing opportunities to implement technologyintegrated instructions to gain more experience.

\section{Çıkar Çatışması Bildirimi}

Yazarlar, bu makalenin araştırılması, yazarlığı veya yayınlanmasına ilişkin herhangi bir potansiyel çıkar çatışması beyan etmemiştir.

\section{Destek/Finansman Bilgileri}

Bu makalenin araştırılmasında Yükseköğretim Kurulu ve TÜBiTAK finansal destek sağlamıştır. 


\section{Etik Kurul Kararı}

Bu araştırma için Orta Doğu Teknik Üniversitesi kurumdan (02.03.2015 tarih 28620816/105-219 sayı no) etik izin alınmıştır. 


\section{References}

Alayyar, G.M. (2011). Developing preservice teacher competencies for ICT integration through design teams. University of Twente. https://doi.org/10.3990/1.9789036532341

Al-rawajfih, K., Fook, F.S., \& Idros, S.N.S. (2010). Stages of Concern in Integrating E-Learning in Discovery Schools. Asian Social Science, 6(8), 54-63. https://doi.org/10.5539/ass.v6n8p54

Anderson, S.E., \& Maninger, R.M. (2007). Preservice Teachers' Abilities, Beliefs, and Intentions regarding Technology Integration. Journal of Educational Computing Research, 37(2), 151-172. https://doi.org/10.2190\%2FH1M8-562W-18J1-634P

Antenos-Conforti, E. (2009). Microblogging on Twitter: Social Networking in Intermediate Italian Classes. In The Next Generation Social Networking and Online Collaboration in Foreign Language Learning (pp. 59-90). San Marcos, Texas: CALICO.

Aşıksoy, G. (2018). ELT students' attitudes and awareness towards the use of WEB 2.0 technologies for language learning. Journal of Language and Linguistic Studies, 14(2), 240-251.

Babbie, E. (2001). Practice of Social Research (9th Ed). Belmont, CA: Wadsworth Thomson Learning.

Bandura, A. (1997). Self-efficacy: The exercise of control. New York: W. H. Freeman.

Borg, S. (2011). The impact of in-service teacher education on language teachers' beliefs. System, 39(3), 370-380. https://doi.org/10.1016/j.system.2011.07.009

Boz, Y., \& Boz, N. (2010). The nature of the relationship between teaching concerns and sense of efficacy. European Journal of Teacher Education, 33(3), 279-291. https://doi.org/10.1080/02619768.2010.490910

Burke, P.F., Schuck, S., Aubusson, P., Kearney, M., \& Frischknecht, B. (2018). Exploring teacher pedagogy, stages of concern and accessibility as determinants of technology adoption. Technology, Pedagogy and Education, 27(2), 149-163. https://doi.org/10.1080/1475939X.2017.1387602

Büyüköztürk, Ş. (2009). Sosyal Bilimler için Veri Analizi El Kitabı. Ankara: Pegem Akademi.

Cephe, P. T., \& Balcikanli, C. (2012). Web 2.0 Tools in Language Teaching: What do Student Teachers Think? International Journal on New Trends in Education and Their Implications, 3(1), 1-12.

Chen, Y.-H., \& Jang, S.-J. (2014). Interrelationship between Stages of Concern and Technological, Pedagogical, and Content Knowledge: A study on Taiwanese senior high school in-service teachers. Computers in Human Behavior, 32, 79-91. https://doi.org/10.1016/j.chb.2013.11.011

Creswell, J.W., \& Clark, V.P. (2007). Designing and Conducting Mixed Methods Research (1st ed.). SAGE Publications.

Cullen, T., \& Greene, B. (2011). Preservice teachers' beliefs, attitudes, and motivation about technology integration. Journal of Educational Computing Research, 45(1), 29-47. https://doi.org/10.2190/EC.45.1.b

Ducate, C.L., \& Lomicka, L.L. (2008). Adventures in the blogosphere: From blog readers to blog writers. Computer Assisted Language Learning, 21(1), 9-28. https://doi.org/10.1080/09588220701865474 
Ertmer, P.A., \& Ottenbreit-Leftwich, A.T. (2010). Teacher technology change: How knowledge, confidence, beliefs, and culture intersect. Journal of Research on Technology in Education, 42(3), 255-284. https://doi.org/10.1080/15391523.2010.10782551

Faizi, R. (2018). Teachers' perceptions towards using Web 2.0 in language learning and teaching. Education and Information Technologies Volume, 23, 1219-1230. https://doi.org/10.1007/s10639-017-9661-7

Fessakis, G., Tatsis, K., \& Dimitracopoulou, A. (2008). Supporting "Learning by Design" Activities Using Group Blogs. Educational Technology \& Society, 11(4), 199-212. Retrieved from https://eric.ed.gov/?id=EJ825111

Field, A. (2009). Discovering Statistics Using SPSS (3rd ed.). Sage Publications.

Firat, E.A., \& Koksal, M.S. (2017). The relationship between use of Web 2.0 tools by prospective science teachers and their biotechnology literacy. Computers in Human Behavior, 70, 44-50. https://doi.org/10.1016/i.chb.2016.12.067

George, A.A., Hall, G.E., \& Stiegelbauer, S.M. (2006). Measuring Implementation in Schools: The Stages of Concern Questionnaire. Austin, TX: SEDL.

Ghaith, G., \& Shaaban, K. (1999). The relationship between perceptions of teaching concerns, teacher efficacy and selected teacher characteristics. Teaching and Teacher Education, 15(5), 487-496. https://doi.org/10.1016/S0742-051X(99)00009-8

Goktas, Y., Yildirim, Z., \& Yildirim, S. (2009). Main Barriers and Possible Enablers of ICTs Integration into Preservice Teacher Education Programs. Educational Technology \& Society, 12(1), 193-204. Retrieved from https://eric.ed.gov/?id=EJ833426

Groth, L.A., Dunlap, K.L., \& Kidd, J.K. (2007). Becoming technology literate through technology integration in PK-12 preservice literacy courses: Three case studies. Reading Research and Instruction, 46(4), 363-386. https://doi.org/10.1080/19388070709558476

Gülbahar, Y. (2008). Improving The Technology Integration Skills of Prospective Teachers Through Practice: A Case Study. The Turkish Online Journal of Educational Technology, 7(4), 71-81. Retrieved from https://eric.ed.gov/?id=EJ1102940

Hall, G.E. (1976). The study of individual teacher and professor concerns about innovations. Journal of Teacher Education, 27(1), 22-23. https://doi.org/10.1177\%2F002248717602700106

Hall, G.E., \& Hord, S.M. (2001). Implementing Change: Patterns, Principles, and Potholes. Boston: Pearson/Allyn \&Bacon.

Hall, G.E., \& Hord, S.M. (2014). Implementing Change: Patterns, Principles, and Potholes (4th ed.). Pearson.

Hall, G.E., George, A.A. (1979). Stages of Concern About the Innovation: The Concept, Initial Verification and Some Implications. Retrieved from https://eric.ed.gov/?id=ED187716

Hall, J.A. (2018). Flipping with the First Principles of Instruction: An Examination of Preservice Teachers' Technology Integration Development. Journal of Digital Learning in Teacher Education, 34(4), 201-218. https://doi.org/10.1080/21532974.2018.1494520

Handal, B., Campbell, C., \& Perkins, T. (2019). Learning About Mobile Learning: Pre-Service Teachers' Perspectives. TechTrends, 63, 711-722. https://doi.org/10.1007/s11528019-00430-1 
Hao, Y., \& Lee, K.S. (2017). Inquiry of preservice teachers' concern about integrating Web 2.0 into instruction. European Journal of Teacher Education, 40(2), 191-209. https://doi.org/10.1080/02619768.2017.1285278

Hur, J.W., Shen, Y.W., Kale, U., \& Cullen, T.A. (2015). An exploration of pre-service teachers intention to use mobile devices for teaching. International Journal of Mobile and Blended Learning, 7(3), 1-17. http://doi.org/10.4018/IJMBL.2015070101

Kayaduman, H., \& Delialioglu, Ö. (2016). Investigating Pre-Service English Teachers Stages of Concern toward Using Wiki. Mersin University Journal of the Faculty of Education, 12(2), 588-600. https://doi.org/10.17860/efd.89600

Kayaduman, H. \& Delialioglu, Ö. (2017). Effect of Learning Technology by Design (LBD) Activities on Technology Integration Self-Efficacy Beliefs of Pre-Service English Teachers. In Proceedings of EdMedia: World Conference on Educational Media and Technology 2017 (pp. 843-849). Association for the Advancement of Computing in Education (AACE). Retrieved from https://www.learntechlib.org/primary/p/178393

Kayaduman, H., \& Demirel, T. (2019). Investigating the Concerns of First-Time Distance Education Instructors. The International Review of Research in Open and Distributed Learning (IRRODL), 20(5), 85-103. https://doi.org/10.19173/irrodl.v20i5.4467

Jauregi, K., \& Banados, E. (2008). Virtual interaction through video-web communication: A step towards enriching and internationalizing language learning programs. ReCALL, 20(2), 183-207. https://doi.org/10.1017/S0958344008000529

Johnson, L.D. (2012). The Effect of Design Teams on Preservice Teachers' Technology Integration. In a Doctoral Dissertation. Syracuse University.

Kalota, F., \& Hung, W.C. (2013). Instructional effects of a performance support system designed to guide preservice teachers in developing technology integration strategies. British Journal of Educational Technology, 44(3), 442-452. https://doi.org/10.1111/j.1467-8535.2012.01318.x

Karaca, F., Can, G., \& Yildirim, S. (2013). A path model for technology integration into elementary school settings in Turkey. Computers \& Education, 68, 353-365. https://doi.org/10.1016/i.compedu.2013.05.017

Kessler, G. (2009). Student-initiated attention to form in wiki-based collaborative writing. Language Learning \& Technology, 13(1), 79-95. Retrieved from https://eric.ed.gov/?id=EJ827542

Kim, K., Jain, S., Westhoff, G., \& Rezabek, L. (2008). A quantitative exploration of preservice teachers' intent to use computer-based technology. Journal of Instructional Psychology, 35(3), 275-287. Retrieved from http://www.projectinnovation.biz/iip 2006.html

Koehler, M.J., \& Mishra, P. (2005). Teachers Learning Technology by Design. Journal of Computing Teacher Education, 21(3), 94-102. Retrieved from https://files.eric.ed.gov/fulltext/EJ882473.pdf

Kolodner, J.L. (2002). Facilitating the learning of design practices: Lessons learned from an inquiry into science education. Journal of Industrial Teacher Education, 39(3), 9-40. Retrieved from https://eric.ed.gov/?id=EJ782298

Kontogeorgi, M. (2014). Exploring the use of Wikis in developing students' writing skills in the EFL classroom. Research Papers in Language Teaching and Learning, 5(1), 123-152. 
Kumar, S. \& Vigil, K. (2011) The Net Generation as Preservice Teachers. Journal of Digital Learning in Teacher Education, 27(4), 144-153.

https://doi.org/10.1080/21532974.2011.10784671

Kurt, G., Mishra, P. \& Kocoglu, Z. (2013). Technological Pedagogical Content Knowledge Development of Turkish Pre-Service Teachers of English. In Proceedings of SITE 2013, 5073-5077. New Orleans, LA. Retrieved from https://www.learntechlib.org/primary/p/48937.

Lee, Y., \&Lee, J. (2014). Enhancing preservice teachers' self-efficacy beliefs for technology integration through lesson planning practice. Computers \& Education, 73, 121-128. https://doi.org/10.1016/j.compedu.2014.01.001

Lei, J. (2009). Digital natives as preservice teachers: What technology preparation is needed? Journal of Computing in Teacher Education, 25(3), 87-97. Retrieved from https://eric.ed.gov/?id=EJ835233

Lincoln, Y.S., \&Guba, E.G. (1985). Naturalistic Inquiry. Newbury Park, CA: Sage Publications.

Lochner, B., Conrad, R.-M., \&Graham, E. (2015). Secondary teachers' concerns in adopting learning management systems: A U.S. perspective. TechTrends, 59(5), 62-70. https://doi.org/10.1007/s11528-015-0892-4

McArthur, A.H. (2008). Exploring relationships between configurations of technology use and professional development among CES teachers. University of Nevada. Retrieved from https://digitalscholarship.unlv.edu/rtds/2794

Miles, M.B., \&Huberman, A.M. (1994). Qualitative data analysis: An expanded sourcebook (2nd ed.). California: SAGE Publications.

O'Reilly, T. (2005). What is Web 2.0: Design Patterns and Business Models for the Next Generation of Software. Retrieved from http://www.oreilly.com/pub/a/web2/archive/what-is-web-20.html

Orehovacki, T., Bubas, G., \& Konecki, M. (2009). Web 2.0 in education and potential factors of Web 2.0 use by students of information systems. Proceedings of the ITI 2009 International Conference on Information Technology Interfaces: Cavtat, Croatia.

Ottenbreit-Leftwich, A.T., Glazewski, K.D., Brush, T.A., Aslan, S., \& Zachmeier, A. (2018). Addressing technology integration concerns: Asynchronous video mentoring between pre-service teachers and exemplary technology-using in-service teachers. Australasian Journal of Educational Technology, 34(4). https://doi.org/10.14742/ajet.3246

Pallant, J. (2007). SPSS Survival Manual (3rd ed.). New York, NY: McGraw-Hill Education.

Patton, M.Q. (2001). Qualitative Research \& Evaluation Methods (3rd ed.). Sage Publications.

Penrod, D. (2007). Using Blogs to Enhance Literacy: The Next Powerful Step in 21st-Century Learning. Lanham, MD: Rowman \& Littlefield Education.

Quadrini, V.H. (2013). Teacher-Education Student Perceptions for Stages of Concern Related to Integrating Technology. The University of West Florida. Retrieved from https://eric.ed.gov/?id=ED564487

Rogers, E.M. (2003). Diffusion of Innovation (5th ed.). New York: Free Press.

Sadaf, A., Newby, T.J., \& Ertmer, P.A. (2016). An investigation of the factors that influence preservice teachers' intentions and integration of Web 2.0 tools. Educational Technology Research and Development, 64(1), 37-64. https://doi.org/10.1007/s11423015-9410-9 
Sari, M.I. (2019). The Use of Web 2.0 Tools for Learning in EFL Context: Pre-service Teachers' Voice. Journal of Foreign Language Teaching and Learning, 4(2), 135-149. https://doi.org/10.18196/ftl.4243

Teo, T. (2009). Modelling technology acceptance in education: A study of preservice teachers. Computers \& Education, 52(2), 302-312. https://doi.org/10.1016/i.compedu.2008.08.006

Teo, T., Lee, C.B., \& Chai, C.S. (2008). Understanding pre-service teachers' computer attitudes: Applying and extending the technology acceptance model. Journal of Computer Assisted Learning, 24(2), 128-143. https://doi.org/10.1111/j.1365-2729.2007.00247.x

Toms, S.A. (1997). Instructional use of the Internet: Stages of concern among faculty at the University of Florida. University of Florida.

Waycott, J., Bennett, S., Kennedy, G., Dalgarno, B., \& Gray, K. (2010). Digital divides? Student and staff perceptions of information and communication technologies. Computers and Education, 54(4), 1202-1211. https://doi.org/10.1016/j.compedu.2009.11.006

Wexler, D.H. (2003). Shifting Pedagogies: Intersections of Computer Supported Technologies, Education, and Power. Syracuse University.

Yang, S.C., \& Huang, Y.-F. (2008). A study of high school English teachers' behavior, concerns and beliefs in integrating information technology into English instruction. Computers in Human Behavior, 24(3), 1085-1103. https://doi.org/10.1016/i.chb.2007.03.009

Yıldırım, A., \& Şimşek, H. (2013). Sosyal Bilimlerde Nitel Araştırma Yöntemleri [Qualitative research methods in the social sciences] (9th ed.). Ankara: Şeçkin.

YÖK. (2018). Eğitim Fakültesi Öğretmen Yetiştirme Lisans Programları [Faculty of Education Teacher Undergraduate Programs]. Retrieved from https://www.yok.gov.tr/kurumsal/idari-birimler/egitim-ogretim-dairesi/yeniogretmen-yetistirme-lisans-programlari

Correspondence

Dr. Halil KAYADUMAN

halilkayaduman@gmail.com

Prof. Dr. Ömer DELIALIOĞLU

omerd@metu.edu.tr 